LEÃO, Celina; FRIAS, Lincoln. Os objetivos da tributação: a interpretação liberal e a interpretação social da propriedade privada. Revista Eletrônica Direito e Política, Programa de Pós-Graduação Stricto Sensu em Ciência Jurídica da UNIVALI, Itajaí, v.12, n.3, $3^{\circ}$ quadrimestre de 2017. Disponível em: www.univali.br/direitoepolitica - ISSN 1980-7791

\title{
OS OBJETIVOS DA TRIBUTAÇÃO: A INTERPRETAÇÃO LIBERAL E A INTERPRETAÇÃO SOCIAL DA PROPRIEDADE PRIVADA
}

\author{
THE PURPOSES OF TAXATION: THE LIBERAL AND THE SOCIAL \\ INTERPRETATIONS OF PRIVATE PROPERTY
}

Celina Leão ${ }^{1}$

Lincoln Frias ${ }^{2}$

SUMÁRIO: Introdução; 1 A interpretação liberal da propriedade privada; 2 A interpretação social da propriedade privada; 3 o princípio da capacidade contributiva; 4 A função social da propriedade; Considerações finais; Referências das fontes citadas

\section{RESUMO}

A cobrança de tributos deve ser utilizada para outras funções além da simples arrecadação de recursos para sustentar o Estado? Usando a revisão de literatura e a análise conceitual, este artigo expõe e compara as interpretações liberal e social da propriedade privada, incluindo uma análise da legislação brasileira e dos princípios da capacidade contributiva e da função social da propriedade. Enquanto a interpretação liberal trata a propriedade como um direito natural que exige que a tributação não altere a distribuição pré-tributária do patrimônio, a interpretação social defende que, por ser uma convenção jurídica, a propriedade privada legalmente protegida é a pós-tributária. Isso significa que o Estado pode usar a tributação para buscar determinados objetivos sociais, tais como estimular o crescimento econômico ou evitar a concentração excessiva de patrimônio, conforme previsto na Constituição Federal de 1988.

PALAVRAS-CHAVES: Tributação; Propriedade Privada; Liberalismo

\section{ABSTRACT}

Should taxation be used for functions other than mere raising of funds to maintain the State? Through literature review and conceptual analysis, this paper exposes and compares the social and liberal interpretations of private property, including an analysis of the Brazilian legislation and the principles of contributive

1 Procuradora da Fazenda Nacional. Mestre em Gestão Pública e Sociedade pela Universidade Federal de Alfenas (UNIFAL-MG). Email: celina.gontijo@uol.com.br

2 Professor do mestrado em Gestão Pública e Sociedade pela Universidade Federal de Alfenas (UNIFAL-MG), campus Varginha-MG, Brasil. Doutor em Filosofia pela Universidade Federal de Minas Gerais (UFMG). Email: lincolnfrias@gmail.com 
LEÃO, Celina; FRIAS, Lincoln. Os objetivos da tributação: a interpretação liberal e a interpretação social da propriedade privada. Revista Eletrônica Direito e Política, Programa de Pós-Graduação Stricto Sensu em Ciência Jurídica da UNIVALI, Itajaí, v.12, n.3, $3^{\circ}$ quadrimestre de 2017. Disponível em: www.univali.br/direitoepolitica - ISSN 1980-7791

capacity and of the social function of private property. Whereas the liberal interpretation treats private property as a natural right requiring that taxation do not alter pre-tax wealth distribution, the social interpretation proposes that, being a social convention, the only legally protected private property is the posttax one. This means that the State can use taxation to pursue certain social purposes, such as the promotion of economic growth or the avoidance of excessive concentration of wealth, as ruled in the Brazilian Federal Constitution (1988).

KEYWORDS: taxation; private property; liberalism

\section{INTRODUÇÃO}

O planejamento do sistema tributário deve ter como objetivo apenas o recolhimento eficiente dos tributos ou deve também se esforçar para levar em consideração todas as implicações sociais da cobrança de tributos? Para responder a essa questão é necessário analisar qual é a relação entre Estado e propriedade privada e sob quais condições ele pode recolher uma parte do patrimônio individual. Há duas interpretações adversárias sobre a relação entre propriedade privada e Estado com profundas implicações para a tributação decorrente delas.

Permeia o senso comum uma interpretação liberal da propriedade privada que entende que o patrimônio individual é algo exclusivo de seu proprietário, que a ele pode dar a destinação que melhor lhe convier. Nessa visão ${ }^{3}$, o tributo seria um montante que o Estado retiraria do indivíduo com o intuito de financiar suas atividades, não podendo a arrecadação ser superior ao necessário para as atividades estatais essenciais, pois atividades supérfluas não seriam importantes o suficiente para justificar essa suposta invasão do Estado na vida privada dos cidadãos.

Por isso, é preciso "fugir do leão", dizem dezenas de reportagens sobre o imposto de renda. O fato de que a visão do sistema tributário como uma fera

3 LOCKE, John. Dois Tratados sobre o Governo. Tradução de Júlio Ficher. São Paulo: Martins Fontes, 2005.

NOZICK, Robert. Anarquia, Estado e Utopia. Tradução de Ruy Jungmann. Rio de Janeiro: JZE, 1991. 
LEÃO, Celina; FRIAS, Lincoln. Os objetivos da tributação: a interpretação liberal e a interpretação social da propriedade privada. Revista Eletrônica Direito e Política, Programa de Pós-Graduação Stricto Sensu em Ciência Jurídica da UNIVALI, Itajaí, v.12, n.3, $3^{\circ}$ quadrimestre de 2017. Disponível em: www.univali.br/direitoepolitica - ISSN 1980-7791

raivosa atacando as pessoas seja tão difundida é uma evidência contundente de que o tributo é visto como uma invasão do Estado na esfera privada, a retirada de algo que pertence ao indivíduo.

Em resposta a essa visão, a interpretação social da propriedade privada ${ }^{4}$ a considera uma convenção jurídica. Isso significaria que a sociedade poderia formular o sistema tributário com a finalidade de atribuir ao patrimônio individual a responsabilidade pelo bem comum, isto é, criando normas tributárias que não tenham a simples arrecadação como objetivo principal, mas sim a melhoria da vida em comum. Por exemplo, tributos mais altos para produtos nocivos à saúde do consumidor, a progressividade do imposto de renda e a tributação adicional para lotes vagos e fazendas improdutivas.

As duas primeiras seções deste artigo apresentam a interpretação liberal e a interpretação social da propriedade privada, respectivamente. A terceira seção introduz a capacidade contributiva como o vetor de uma tributação equitativa. Na seção seguinte, é analisado o uso da tributação para a defesa da função social da propriedade. Por fim, são feitas as considerações finais.

\section{A INTERPRETAÇÃO LIBERAL DA PROPRIEDADE PRIVADA}

O século XVII na Inglaterra foi marcado pelo antagonismo entre absolutismo e liberalismo. Após uma guerra civil e um breve período republicano, a Revolução Gloriosa de 1688 reinstaurou a monarquia, porém com um Parlamento de inspiração liberal limitando os poderes do monarca. De origem burguesa liberal, John Locke despontou como oposição ao absolutismo ${ }^{5}$.

Esse contexto histórico é importante para entender o pensamento de Locke e sua defesa da propriedade privada, cujo Segundo Tratado sobre o Governo Civil é um

4 MURPHY, Liam; NAGEL, Thomas. 0 mito da propriedade. Tradução de Marcelo Brandão Cipolla. São Paulo: Martins Fontes, 2005.

5 MELLO, Leonel Itaussu Almeida. Jonh Locke e o individualismo liberal. In: WEFFORT, Francisco C. (Org.). Os clássicos da política. 13 ed. São Paulo: Ática, 2000. v.1. p. 79-110. 
LEÃO, Celina; FRIAS, Lincoln. Os objetivos da tributação: a interpretação liberal e a interpretação social da propriedade privada. Revista Eletrônica Direito e Política, Programa de Pós-Graduação Stricto Sensu em Ciência Jurídica da UNIVALI, Itajaí, v.12, n.3, $3^{\circ}$ quadrimestre de 2017. Disponível em: www.univali.br/direitoepolitica - ISSN 1980-7791

marco da defesa do Estado Liberal ${ }^{6}$. Locke, juntamente com Hobbes e Rousseau, também foi um dos grandes pensadores do jusnaturalismo, segundo o qual os direitos básicos de vida, liberdade e propriedade pertencem naturalmente às pessoas, isto é, não precisam de regulamentação para existir. Para Locke7, por meio do trabalho o homem conseguiria retirar a matéria bruta que se encontrava na natureza e transformá-la em sua propriedade. Logo, a propriedade privada era justificada pelo trabalho que o homem empregou para obtê-la, sendo a apropriação privada uma decorrência natural da razão humana ${ }^{8}$.

No liberalismo, assim como o homem é proprietário exclusivo de seu corpo, ele também é proprietário do seu trabalho e da obra fruto do seu trabalho ${ }^{9}$. Somente enquanto estivesse na natureza, a coisa seria comum a todos os homens. A diferença na propriedade seria resultado do uso diferenciado que cada um faz de seu trabalho. Por isso, a teoria liberal da propriedade é uma teoria deontológica ${ }^{10}$, ou seja, o importante é a legitimidade da ação que origina a propriedade, no caso, o trabalho, independentemente da consequência social que a propriedade possa trazer.

O Estado e a sociedade politicamente organizada surgem com o contrato social estabelecido entre os homens pois, apesar da relativa paz que havia no "estado de natureza", era preciso uma instituição que cuidasse dos conflitos de violação da propriedade privada, para evitar um "estado de guerra"11. Porém, enquanto

6 MELLO, Leonel Itaussu Almeida. Jonh Locke e o individualismo liberal.

7 LOCKE, John. Dois Tratados sobre o Governo. p. 423-424.

8 ALVES, Marco Antônio Sousa. O direito de apropriação privada em Locke: um pensamento de transição. Revista Controvérsia, São Leopoldo, v. 6, n. 3. set/dez 2010. p. 54.

9 LOCKE, John. Dois Tratados sobre o Governo.

10 MURPHY, Liam; NAGEL, Thomas. O mito da propriedade.

11 MELLO, Leonel Itaussu Almeida. Jonh Locke e o individualismo liberal. p. 93. 
LEÃO, Celina; FRIAS, Lincoln. Os objetivos da tributação: a interpretação liberal e a interpretação social da propriedade privada. Revista Eletrônica Direito e Política, Programa de Pós-Graduação Stricto Sensu em Ciência Jurídica da UNIVALI, Itajaí, v.12, n.3, $3^{\circ}$ quadrimestre de 2017. Disponível em: www.univali.br/direitoepolitica - ISSN 1980-7791

Hobbes procura legitimar o Estado Absoluto, Locke busca limitá-lo, dando primazia ao interesse privado ${ }^{12}$.

Chega-se, assim, ao ponto mais importante da teoria liberal para a discussão do presente trabalho que é a defesa de que a propriedade privada é anterior ao Estado e este é aceito unicamente para conservar essa propriedade privada ${ }^{13}$. 0 Estado é posterior à existência humana, logo não poderia violar aquilo que é um direito natural do homem: a vida, a liberdade e a propriedade privada. Para o liberalismo, o Estado não poderia intervir na propriedade privada ou na quantidade de patrimônio que cada um possui legitimamente, tendo cada homem direito àquilo que conquistou com seu trabalho. A tributação seria a retirada pelo Estado de parte do patrimônio privado para financiar as atividades estatais.

Decorre dessa visão, a ideia de que o Estado não tem o direito de usar a tributação para alterar o estado pré-tributação da distribuição de propriedade privada, pois isso indicaria que o Estado não tratou a todos igualmente, na medida em que retirou mais de alguns e menos de outros. Se o único papel da tributação é a manutenção do Estado que o homem consentiu que existisse para a conservação de sua propriedade privada, a tributação deve ser apenas aquela necessária para efetivar as tarefas públicas "naturais", quais sejam, segurança nacional, ordem pública e serviços públicos indivisíveis (tais como construção de infraestrutura rodoviária e portuária, atividades judiciais etc.).

O tributo é, ao mesmo tempo, uma fonte de recursos para o Estado e a garantia para o cidadão de que viverá em um estado fiscal, ou seja, viverá em um Estado que se sustenta pela arrecadação de tributos e permite ao cidadão ter propriedade privada, ao contrário do que ocorria no regime absolutista anterior

12 BELLO, Enzo. A teoria política da propriedade na Era Moderna: ascensão e crítica do individualismo possessivo. In: MOTA, Maurício (Org.). Transformações do Direito de Propriedade Privada. Rio de Janeiro: Elsevier, 2009. p. 129-146.

13 LOCKE, John. Dois Tratados sobre o Governo. 
LEÃO, Celina; FRIAS, Lincoln. Os objetivos da tributação: a interpretação liberal e a interpretação social da propriedade privada. Revista Eletrônica Direito e Política, Programa de Pós-Graduação Stricto Sensu em Ciência Jurídica da UNIVALI, Itajaí, v.12, n.3, $3^{\circ}$ quadrimestre de 2017. Disponível em: www.univali.br/direitoepolitica - ISSN 1980-7791

ao liberalismo, em que o Estado era proprietário de todas as terras e da exploração desse patrimônio retirava seu sustento ${ }^{14}$.

A grande difusão e aceitação do liberalismo pela maioria dos países lhe deram força para influenciar um pensamento econômico que ganhou grande destaque nas últimas décadas do século $X X$, o neoliberalismo. Este surge como uma reação ao Estado do Bem-Estar Social que, diferente do Liberal, vê a atuação estatal como necessária para o desenvolvimento, a diretriz que dominava os governos da Europa Central após a $2^{a}$ Guerra Mundial.

Friedrich August Von Hayek, um dos precursores do neoliberalismo, defendeu em sua obra O Caminho da Servidão, de 1944, que os indivíduos deveriam ser livres para agir como quisessem, devendo o Estado criar condições favoráveis ao progresso, mas não planejar como deve ser o progresso, determinando obrigações aos cidadãos. O sistema da livre concorrência, ideia central do livro, seria o único em que a aquisição da propriedade privada não é um privilégio ou um "favor dos poderosos"15, mas sim uma decorrência do esforço de cada um, sendo o capitalismo o único sistema viável para a sobrevivência da democracia. Segundo o neoliberalismo, para retomar o crescimento era preciso incentivar os agentes econômicos por meio da redução da tributação sobre os altos rendimentos, acompanhada de uma "saudável desigualdade"16.

Um dos componentes centrais do neoliberalismo é sua visão ético-política - o libertarismo (ou libertarianismo) - que preceitua ter cada um o direito incondicional de dispor de sua renda e de sua propriedade como quiser, pois elas

14 NABAIS, José Casalta. 0 dever fundamental de pagar impostos. 3 ed. Lisboa: Almedina, 2012. p. 59-60.

15 HAYEK, Friedrich August von. O caminho da servidão. Tradução de Anna Maria Capovilla, José Ítalo Stelle e Liane de Morais Ribeiro. São Paulo: Instituto Ludwig von Mises Brasil, 2010. p. 114.

16 ANDERSON, Perry. Balanço do Neoliberalismo. In: SADER, Emir; GENTILI, Pablo (Orgs.). Pósneoliberalismo: as políticas sociais e o Estado democrático. Rio de Janeiro: Paz e Terra, 1995. p. 10. 
LEÃO, Celina; FRIAS, Lincoln. Os objetivos da tributação: a interpretação liberal e a interpretação social da propriedade privada. Revista Eletrônica Direito e Política, Programa de Pós-Graduação Stricto Sensu em Ciência Jurídica da UNIVALI, Itajaí, v.12, n.3, $3^{\circ}$ quadrimestre de 2017. Disponível em: www.univali.br/direitoepolitica - ISSN 1980-7791

são frutos de sua conquista, na livre atuação do mercado ${ }^{17}$. O homem teria valor em si próprio e não poderia ter seu interesse violado em prol da sociedade. "De cada um segundo o que ele resolver fazer, a cada um segundo o que ele faz por si mesmo"18.

Segundo Nozick, um dos expoentes do libertarismo, "o Estado mínimo é o mais extenso que se pode justificar ${ }^{\prime \prime 19}$. Considerando que os indivíduos seriam fins em si mesmos e não meios, eles não poderiam ser utilizados como meios para atingir objetivos que não são seus. O Estado não poderia impor que um cidadão contribuísse para com outro, abrindo mão de parte daquilo que conquistou com seus esforços. "A cooperação social turva as águas e torna obscuro ou indeterminado quem tem direito ao quê" ${ }^{\prime 20}$. O sistema de propriedade, assim, seria retributivo, tendo cada um aquilo que legitimamente conquistou com seu trabalho, não sendo legítima nenhuma atividade redistributiva da propriedade imposta aos indivíduos pelo Estado.

Para essa teoria seria legítima a propriedade privada que cada um obtém, independente do grau de concentração ou do uso desse patrimônio. Ao Estado caberia proteger essa realidade, retirando do indivíduo patrimônio por meio da tributação apenas para manter os serviços governamentais essenciais para proteger essa mesma propriedade. A desigualdade seria natural (dadas as diferentes preferências dos indivíduos) e necessária ao sistema produtivo (como forma de estimular o esforço e a tomada de riscos).

Um último elemento essencial da interpretação liberal é a defesa de que o sistema tributário deve ser baseado no princípio do benefício: cada um deve contribuir conforme o benefício que recebe do Estado em forma de serviços

17 MURPHY, Liam; NAGEL, Thomas. O mito da propriedade. p. 48.

18 NOZICK, Robert. Anarquia, Estado e Utopia. p. 180.

19 NOZICK, Robert. Anarquia, Estado e Utopia. p. 170

20 NOZICK, Robert. Anarquia, Estado e Utopia. p. 204-205. 
LEÃO, Celina; FRIAS, Lincoln. Os objetivos da tributação: a interpretação liberal e a interpretação social da propriedade privada. Revista Eletrônica Direito e Política, Programa de Pós-Graduação Stricto Sensu em Ciência Jurídica da UNIVALI, Itajaí, v.12, n.3, $3^{\circ}$ quadrimestre de 2017. Disponível em: www.univali.br/direitoepolitica - ISSN 1980-7791

estatais, de segurança e de infraestrutura, por exemplo ${ }^{21}$, independentemente da quantidade de patrimônio que possua. Por exemplo, Adam Smith, outro clássico do liberalismo, defende que os tributos possuem uma natureza remuneratória, devendo os cidadãos contribuírem na proporção do influxo de benefícios estatais que recebem ${ }^{22}$. Essa ideia está no senso comum da população que apregoa ser injusto pagar impostos diante de corriqueiras situações de atividade estatal não corretamente prestada, tais como vias públicas mal conservadas.

Esse tipo de crítica tem grande apelo. No entanto, ele revela algo profundo e sutil sobre como os tributos são compreendidos. Quando se exige uma contrapartida específica, o tributo está sendo compreendido apenas na sua feição de taxa ${ }^{23}$, em que ao pagamento corresponde uma contraprestação estatal. Porém, como será visto na próxima seção, à sedução dessa visão do tributo como retorno do benefício recebido, a interpretação social propõe uma compreensão do tributo como criador da propriedade, não como seu limitador.

Em resumo, para a interpretação liberal, a propriedade privada é um direito natural, anterior ao Estado, e portanto, ele não tem o direito de alterar sua distribuição, independentemente de seu grau de concentração. Por isso, a tributação mínima, proporcional à prestação de serviços que cada cidadão recebe do Estado.

21 MURPHY, Liam; NAGEL, Thomas. 0 mito da propriedade. p. 22-28.

22 NABAIS, José Casalta. 0 dever fundamental de pagar impostos. p. 449.

23 "As taxas [...] tem como fato gerador o exercício regular do poder de polícia, ou a utilização, efetiva ou potencial, de serviço público específico e divisível, prestado ao contribuinte ou posto à sua disposição", segundo art. 77 do Código Tributário Nacional. BRASIL, Lei no 5.172, de 25 de outubro de 1966. Dispõe sobre o Sistema Tributário Nacional e institui normas gerais de direito tributário aplicáveis à União, Estados e municípios. Diário Oficial da União, Poder Executivo, Brasília, DF, 27 out. 1966. Disponível em: <http://www. planalto.gov.br/ccivil_03/Leis /L5172.htm>. Acesso em: 26 outubro 2015. 
LEÃO, Celina; FRIAS, Lincoln. Os objetivos da tributação: a interpretação liberal e a interpretação social da propriedade privada. Revista Eletrônica Direito e Política, Programa de Pós-Graduação Stricto Sensu em Ciência Jurídica da UNIVALI, Itajaí, v.12, n.3, $3^{\circ}$ quadrimestre de 2017. Disponível em: www.univali.br/direitoepolitica - ISSN 1980-7791

\section{A INTERPRETAÇÃO SOCIAL DA PROPRIEDADE PRIVADA}

$\mathrm{Na}$ contramão do pensamento liberal, a interpretação social da propriedade privada propõe outra concepção da relação propriedade privada, Estado e tributação. Segundo essa interpretação, a propriedade privada é resultado do ordenamento jurídico vigente, em especial do sistema tributário de cada país, sendo aquilo que a legislação permite que exista. Portanto, o direito à propriedade privada não seria um direito natural, mas sim um acordo, uma convenção jurídica24.

De acordo com essa interpretação, somente porque há um Estado e uma legislação que protegem tal direito à propriedade privada é que cada indivíduo pode exercê-lo. Logo, a propriedade seria resultante da convenção social manifestada na legislação, seria aquilo que a pessoa possui após a incidência da tributação, após a conformação que the é dada pela legislação. Trata-se de uma interpretação solidária sobre a natureza da propriedade privada, sendo o sistema tributário o instrumento por meio do qual o Estado concretiza determinada concepção de justiça econômica ou distributiva ${ }^{25}$.

A depender da indagação sobre quais são os direitos e deveres do Estado para com seus cidadãos e vice-versa, e ainda quais são os direitos e deveres dos cidadãos em relação aos outros cidadãos, o sistema tributário deverá ser delineado para permitir que o indivíduo retenha consigo todo o patrimônio que alcançou na economia de mercado ou para estabelecer que o indivíduo tenha o dever de contribuir para diminuir a desigualdade da população na situação póstributária. Para a interpretação social, o tributo não pode ser encarado simplesmente como algo feito contra a vontade dos cidadãos, mas sim como um esforço indispensável para uma vida em comum próspera para todos os membros da comunidade organizada em um Estado ${ }^{26}$.

24 MURPHY, Liam; NAGEL, Thomas. O mito da propriedade. p. 11-13.

25 MURPHY, Liam; NAGEL, Thomas. 0 mito da propriedade. p. 5.

26 NABAIS, José Casalta. O dever fundamental de pagar impostos. p. 185. 
LEÃO, Celina; FRIAS, Lincoln. Os objetivos da tributação: a interpretação liberal e a interpretação social da propriedade privada. Revista Eletrônica Direito e Política, Programa de Pós-Graduação Stricto Sensu em Ciência Jurídica da UNIVALI, Itajaí, v.12, n.3, $3^{\circ}$ quadrimestre de 2017. Disponível em: www.univali.br/direitoepolitica - ISSN 1980-7791

Sob essa perspectiva, o sistema tributário deve tratar todos de forma equitativa, respeitando a máxima aristotélica de dar tratamento desigual aos desiguais, na medida de suas desigualdades. A diferença pré-tributária no patrimônio dos cidadãos permite uma carga tributária diferenciada, sob a forma de alíquotas progressivas (maiores alíquotas quanto maiores a renda ou o patrimônio).

Como visto na seção anterior, segundo a interpretação liberal, para que um tributo seja justo é suficiente que o indivíduo receba serviços estatais proporcionais à magnitude do tributo (princípio do benefício) ${ }^{27}$. A quantidade de patrimônio do indivíduo seria irrelevante para a avaliação da justiça tributária, já que ela deve ser apenas retributiva, nunca redistributiva.

Por outro lado, para a interpretação social, a tributação justa é aquela que considera a capacidade contributiva de cada cidadão, estabelecendo uma alíquota progressiva conforme a quantidade de patrimônio do contribuinte, para exigir tributos com igualdade de sacrifícios relativos para pessoas com realidades patrimoniais diferentes. A justiça da tributação seria um meio legítimo de redistribuição de renda 28 .

\section{O PRINCÍPIO DA CAPACIDADE CONTRIBUTIVA}

O respeito à capacidade contributiva é um direito à repartição racional dos encargos públicos, previsto no $\S 1^{\circ}$ do art. 145 da CF/88:

27 MURPHY, Liam; NAGEL, Thomas. 0 mito da propriedade. p. 22.

28 MURPHY, Liam; NAGEL, Thomas. O mito da propriedade. p. 101. 
LEÃO, Celina; FRIAS, Lincoln. Os objetivos da tributação: a interpretação liberal e a interpretação social da propriedade privada. Revista Eletrônica Direito e Política, Programa de Pós-Graduação Stricto Sensu em Ciência Jurídica da UNIVALI, Itajaí, v.12, n.3, $3^{\circ}$ quadrimestre de 2017. Disponível em: www.univali.br/direitoepolitica - ISSN 1980-7791

Sempre que possível, os impostos terão caráter pessoal e serão graduados segundo a capacidade econômica do contribuinte, facultado à administração tributária, especialmente para conferir efetividade a esses objetivos, identificar, respeitados os direitos individuais e nos termos da lei, o patrimônio, os rendimentos e as atividades econômicas do contribuinte 29 .

Em outras palavras, a capacidade contributiva éa "idoneidade econômica para suportar, sem sacrifício do indispensável à vida compatível com a dignidade humana, uma fração qualquer do custo total dos serviços públicos"30. conteúdo do que se entende por essa capacidade deve ser preenchido por critérios como justiça fiscal, igualdade, isonomia, proporcionalidade e necessidades de subsistência do contribuinte ${ }^{31}$.Trata-se de um princípio que impede a arbitrariedade na definição da tributação ${ }^{32}$. Portanto, a capacidade contributiva é um limite ao poder de tributar.

Dever-se-ia, por exemplo, estabelecer um número maior de alíquotas do imposto de renda pessoa física (IRPF) para abarcar um universo tão diversificado de contribuintes que não é representado pelas atuais quatro alíquotas previstas na Lei no $12.469 / 11^{33}$. Todos os cidadãos que possuem renda mensal acima de $\mathrm{R} \$$ 4.664,68 são tributados pela mesma alíquota de $27,5 \%$ de IRPF, sendo claro que há situações bastante díspares entre aqueles que possuem acima de tal renda,

29 BRASIL. Assembleia Nacional Constituinte. Constituição da República Federativa do Brasil de 05 de Outubro de 1988. Disponível em: http://www.planalto.gov.br/ccivil_03/ Constituicao/Constituicao.htm. Acesso em: 1 junho 2015.

30 BALEEIRO, Aliomar. Limitações constitucionais ao poder de tributar. 7 ed. Rio de Janeiro: Forense, 1997. p. 272.

31 GREGÓRIO, Argos. Análise Doutrinária sobre o conceito de "capacidade contributiva" e a eleição de critérios para a sua formulação. Revista Brasileira de Direito Tributário e Finanças Públicas, São Paulo, n. 12, p. 5-20, jan./fev. 2009.

NABAIS, José Casalta. $\mathbf{O}$ dever fundamental de pagar impostos.

32 NABAIS, José Casalta. $\mathbf{O}$ dever fundamental de pagar impostos.

33 BRASIL. Presidência da República. Lei no 12.469 de 26 de agosto de 2011. Altera os valores constantes da tabela do Imposto sobre a Renda da Pessoa Física. Disponível em: <http://www. planalto.gov.br/CCIVIL_03/_Ato2011-2014/2011/Lei/L12469.htm>. Acesso em: 10 novembro 2015. 
LEÃO, Celina; FRIAS, Lincoln. Os objetivos da tributação: a interpretação liberal e a interpretação social da propriedade privada. Revista Eletrônica Direito e Política, Programa de Pós-Graduação Stricto Sensu em Ciência Jurídica da UNIVALI, Itajaí, v.12, n.3, $3^{\circ}$ quadrimestre de 2017. Disponível em: www.univali.br/direitoepolitica - ISSN 1980-7791

não havendo respeito à capacidade contributiva por uma legislação que não leva em conta uma diferença econômica tão grande.

A política tributária deve colocar em prática um sistema que em todo o seu conjunto respeite a capacidade contributiva, viabilizando que a arrecadação necessária para os serviços e programas do Estado tenha fonte naquele que efetivamente manifestou capacidade de pagar, por meio de uma tributação progressiva que realiza justiça social. Exemplo prático de tributação progressiva para atender de forma justa as realidades mais díspares, na Alemanha as alíquotas do imposto sobre a herança variam de 3 a 70\%, conforme o valor do bem transmitido e da distância na relação de parentesco entre o falecido e o herdeiro ${ }^{34}$, demonstrando a possibilidade de um imposto real ser graduado conforme a capacidade contributiva, buscando onerar de maneira justa patrimônios tão diversos.

Dessa maneira, a hipótese liberal de que seria justo o indivíduo manter o patrimônio que conquistou por seus esforços no mercado livre, não podendo a tributação interferir no patrimônio de cada um, seria contraditória, pois o mercado só existe porque há um Estado que promulga as leis que o possibilita (gestão do sistema monetário, proteção à concorrência, falência, patentes, copyright etc.). O Estado se sustenta com os recursos gerados pelo mercado, mas o mercado depende das regulações estatais para funcionar. Uma evidência disso são os saques que acontecem em algumas tragédias naturais. Nesses casos, o Estado se torna temporariamente incapaz de impor sua existência, o que faz com que alguns indivíduos antes ordeiros passem a não se comportar de acordo com as regras de mercado que exigem que a posse das mercadorias só aconteça mediante pagamento.

Alguém poderia argumentar que o Estado tem precedência sobre o mercado porque é possível sustentar um Estado sem a existência de um mercado. Por exemplo, em um Estado ditatorial e escravocrata, com preços completamente

34 TORRES, Ricardo Lobo. Tratado de Direito Constitucional Financeiro e Tributário. Rio de Janeiro: Renovar, 2007. v. 4. p. 227. 
LEÃO, Celina; FRIAS, Lincoln. Os objetivos da tributação: a interpretação liberal e a interpretação social da propriedade privada. Revista Eletrônica Direito e Política, Programa de Pós-Graduação Stricto Sensu em Ciência Jurídica da UNIVALI, Itajaí, v.12, n.3, $3^{\circ}$ quadrimestre de 2017. Disponível em: www.univali.br/direitoepolitica - ISSN 1980-7791

controlados. No entanto, ao menos dois contra-argumentos seriam possíveis: (a) provavelmente esse tipo de economia não seja sustentável por muito tempo nos dias atuais; (b) mesmo nesses casos, provavelmente há espaço para o funcionamento dos mecanismos de oferta e demanda de serviços e produtos.

Como ambos já existiram sob diversas formas, uma investigação histórica e antropológica sobre essa questão exigiria espaço e nuances além do escopo do presente trabalho. Isso não é um problema para a interpretação social da propriedade privada, pois ela pode se basear em uma hipótese menos agressiva: Estado e mercado criam-se mutuamente, assim como não é possível existir mercado sem a imposição de regras (Estado), não é possível sustentar a imposição de regras sem que que existam trocas voluntárias que gerem valor e permitam a divisão social do trabalho (mercado).

Dado que o mercado supõe o funcionamento do Estado para que possa existir, "é logicamente impossível que as pessoas tenham algum tipo de direito sobre a renda que acumulam antes de pagar impostos. Só podem ter direito ao que lhes sobra depois de pagar os impostos sob um sistema legítimo"35. Obviamente, também é impossível falar em propriedade privada sem que exista um mercado, pois é justamente a existência de trocas voluntárias de bens e serviços que cria a necessidade da noção de que há coisas que pertencem a certas pessoas.

Diferentemente da visão deontológica sobre a legitimidade da propriedade privada, a interpretação social da propriedade é consequencialista, isto é, defende que a propriedade individual deve ser avaliada de acordo com seus efeitos sobre a sociedade e, por ser uma decorrência da lei, deve ser regulada dependendo da promoção dos valores sociais que se almeja ${ }^{36}$. Apenas sob esse pano de fundo é possível que a Constituição Federal de 1988 nos arts. $3^{\circ}$ e $5^{037}$ tenha estabelecido como direito fundamental que a propriedade privada possui

35 MURPHY, Liam; NAGEL, Thomas. O mito da propriedade. p. 46.

36 MURPHY, Liam; NAGEL, Thomas. O mito da propriedade. p. 60-61.

37 BRASIL. Assembleia Nacional Constituinte. Constituição da República Federativa do Brasilde 05 de Outubro de 1988. 
LEÃO, Celina; FRIAS, Lincoln. Os objetivos da tributação: a interpretação liberal e a interpretação social da propriedade privada. Revista Eletrônica Direito e Política, Programa de Pós-Graduação Stricto Sensu em Ciência Jurídica da UNIVALI, Itajaí, v.12, n.3, $3^{\circ}$ quadrimestre de 2017. Disponível em: www.univali.br/direitoepolitica - ISSN 1980-7791

uma função social e que o direito de propriedade só é legitimamente exercido se contribuir para alcançar os objetivos de construção de uma sociedade justa e solidária.

A solidariedade se expressa por meio de uma política tributária que considere que o valor marginal do dinheiro, isto é, a utilidade efetiva de uma mesma quantidade de dinheiro, diminui conforme aumenta o montante patrimonial individual. Uma alíquota de $1 \%$ sobre a renda alcança $R \$ 1,00$ daquele que tem renda mensal de $\mathrm{R} \$ 100,00$ e $\mathrm{R} \$ 100,00$ daquele que tem renda de $\mathrm{R} \$$ $10.000,00$. No entanto, a utilidade de $R \$ 1,00$ para aquele que tem uma renda de $R \$ 100,00$ é muito maior do que os $R \$ 100,00$ para quem tem renda de $R \$$ $10.000,00$. Assim, embora à primeira vista possa parecer justo tributar todos de forma proporcional a sua capacidade por meio de uma alíquota única, tem-se que o valor marginal do dinheiro faz com que a mesma alíquota provoque um sacrifício maior para aquele que possui pouca renda ou patrimônio. Logo, para efetivar a solidariedade, a política tributária deve levar em conta a real capacidade contributiva do cidadão, implantando-se um sistema tributário progressivo.

Isso mostra o equívoco do princípio do benefício, defendido pela interpretação liberal da propriedade privada. Uma diretriz mais adequada é dada pelo princípio da capacidade contributiva: cada cidadão deve contribuir na medida de sua capacidade financeira, para que sejam prestados os serviços estatais a quem necessita, sendo o patrimônio de todos chamado a cumprir sua função social.

O tributo é essencial para a vida em sociedade e todos devem contribuir na medida de sua capacidade econômica para a existência do Estado e de uma sociedade mais justa. Na Constituição Brasileira ${ }^{38}$ há diversas normas que refletem o princípio da solidariedade social, dentre elas, a extrafiscalidade no ITR e no IPTU para cumprimento da função social da propriedade (art. 153, §40 e art. $\left.156, \S 1^{\circ}\right)$, o tratamento tributário diferenciado às cooperativas e outras

38 BRASIL. Assembleia Nacional Constituinte. Constituição da República Federativa do Brasilde 05 de Outubro de 1988. 
LEÃO, Celina; FRIAS, Lincoln. Os objetivos da tributação: a interpretação liberal e a interpretação social da propriedade privada. Revista Eletrônica Direito e Política, Programa de Pós-Graduação Stricto Sensu em Ciência Jurídica da UNIVALI, Itajaí, v.12, n.3, $3^{\circ}$ quadrimestre de 2017. Disponível em: www.univali.br/direitoepolitica - ISSN 1980-7791

formas de associativismo (art. 146, inc. III, alínea c, e art. 174, §20), a imunidade das instituições de assistência social (art. 150, inc. VI, alínea c, § 40 e art. $195, \S 7^{\circ}$ ) e o sistema previdenciário contributivo e solidário (art. 194). Mas, além dessas normas, o sistema tributário como um todo deve ser progressivo, isto é, não apenas cada um dos tributos, mas o seu conjunto deve também levar em consideração a progressividade. "O princípio da progressividade representa o custo da solidariedade" 39 .

Em um Estado que tem por objetivo a construção de uma sociedade justa e solidária o tributo não deve ser visto como usurpação do patrimônio privado pelo Estado; o tributo é necessário para que o Estado e a sociedade organizada existam, sendo o patrimônio privado aquele que deriva da legislação, após a incidência da tributação. Além de arrecadar, pode o tributo ser utilizado em sua outra face, a extrafiscalidade, para atingir os objetivos estatais. Para compreender melhor como a interpretação social da propriedade privada se concretiza no sistema tributário, é necessário detalhar esse aspecto.

\section{A FUNÇÃO SOCIAL DA PROPRIEDADE}

A extrafiscalidade dos tributos é a consequência da norma tributária que ultrapassa a mera arrecadação de tributo ${ }^{40}$. Isto é, ela acontece quando o tributo serve para proteger o mercado interno, induzir ou inibir uma atividade comercial, estimular a exportação de determinado produto, permitir a forma federativa de Estado, reduzir ou elevar a concentração do patrimônio etc.

A extrafiscalidade manifesta-se por meio de isenções, benefícios fiscais, parcelamentos, progressividade ou regressividade de alíquotas, para, criando diferenças entre os atores econômicos, buscar atingir uma maior justiça fiscal com desenvolvimento econômico. Isso mostra que o sistema tributário pode

39 SACCHETO, Cláudio. O dever de solidariedade no Direito Tributário: o Ordenamento Italiano. In: GRECO, Marco Aurélio; GODOI, Marciano Seabra (Orgs.). Solidariedade Social e Tributação. São Paulo: Dialética, 2005. p. 25.

40 LEAL, Augusto Cesar de Carvalho. (In) Justiça Social por meio dos tributos: a finalidade redistributiva da tributação e a regressividade da matriz tributária brasileira. 
LEÃO, Celina; FRIAS, Lincoln. Os objetivos da tributação: a interpretação liberal e a interpretação social da propriedade privada. Revista Eletrônica Direito e Política, Programa de Pós-Graduação Stricto Sensu em Ciência Jurídica da UNIVALI, Itajaí, v.12, n.3, $3^{\circ}$ quadrimestre de 2017. Disponível em: www.univali.br/direitoepolitica - ISSN 1980-7791

interferir na vida social não apenas quando cobra um valor em pecúnia do cidadão, mas também quando deixa de cobrar (isenções, benefícios fiscais etc.). Em uma mesma norma pode haver convivência dos efeitos fiscal e extrafiscal, não sendo expressa a índole de seu conteúdo. Tal classificação decorre do teor da norma e da sua finalidade, do "modo como se dá a utilização do instrumental jurídico-tributário"41.

Para alguns, a extrafiscalidade deixou de ser um "poder" para ser um "dever" constitucional com o intuito de atingir as finalidades econômicas, sociais e políticas pretendidas ${ }^{42}$.

Os estudos tributários normalmente se restringem a analisar a conformação legal do tributo, as características da hipótese de incidência, da base de cálculo, dos sujeitos ativo e passivo, dando proeminência ao conceito de tributo como "prestação pecuniária compulsória" não decorrente de ato ilícito, tal como estabelecido no art. $3^{\circ}$ do Código Tributário Nacional (CTN). Essa visão do tributo focada na norma impositiva se enquadra na teoria formalista do direito tributário ${ }^{43}$, deixando ao largo qualquer consideração de ordem econômica, "prélegislativa", financeira ou outras. A realidade das relações sociais e econômicas, no entanto, revela que a importância do tributo vai muito além de meio arrecadatório, de prestação pecuniária, na qual o cidadão se obriga financeiramente perante o Estado.

Quando são levados em consideração todos os efeitos econômicos e sociais que pode gerar ao estimular ou desestimular determinados comportamentos (investimentos, doações, tabagismo, consumo de álcool, cuidado com o meio ambiente etc.), o tributo torna-se instrumento de transformação social por meio das consequências de sua imposição ou desoneração em diversos campos de

41 CARVALHO, Paulo de Barros. Curso de Direito Tributário. 17 ed. São Paulo: Saraiva, 2005. p. 234.

42 NABAIS, José Casalta. O dever fundamental de pagar impostos. p. 240-245.

43 GRECO, Marco Aurélio. Crise do Formalismo no Direito Tributário Brasileiro. Revista da Procuradoria Geral da Fazenda Nacional, Brasília, v.1, n.1, p. 9-18, jan./jul. 2011. 
LEÃO, Celina; FRIAS, Lincoln. Os objetivos da tributação: a interpretação liberal e a interpretação social da propriedade privada. Revista Eletrônica Direito e Política, Programa de Pós-Graduação Stricto Sensu em Ciência Jurídica da UNIVALI, Itajaí, v.12, n.3, $3^{\circ}$ quadrimestre de 2017. Disponível em: www.univali.br/direitoepolitica - ISSN 1980-7791

atividades estatais ou da iniciativa privada, como a economia, o meio ambiente, a educação e a cultura. Para entender e melhor aplicar essa outra feição do tributo, a extrafiscalidade, é preciso que se considere a teoria finalista do direito tributário ${ }^{44}$. Esta se caracteriza por defender que os sistemas tributário e financeiro estão subordinados à finalidade máxima de realização dos direitos fundamentais dos cidadãos, não sendo sistemas estanques ou solitários, que não influenciam nem são influenciados por outras áreas.

$\mathrm{Na} \mathrm{CF} / 88^{45}$ há expressa previsão de extrafiscalidade para alguns tributos, como a instituição de contribuição de intervenção do Estado no domínio econômico (art. 149), a seletividade na alíquota do imposto sobre produtos industrializados (IPI, art. $153, \S 3^{\circ}$ ) e a progressividade nas alíquotas do imposto sobre a propriedade urbana (IPTU) e rural (ITR) para incentivar a função social da propriedade (art. $153, \S 4^{\circ}$, e art. $\left.156, \S^{\circ}\right)$. A próxima seção se dedica a detalhar melhor um dos principais usos da extrafiscalidade, o emprego da tributação com o intuito de garantir a função social da propriedade.

A CF/88, ao estabelecer os direitos fundamentais do cidadão, preceitua que é garantido a todos o direito à propriedade privada, a qual atenderá sua função social (inc. XXII e XXIII do art. 50) ${ }^{46}$. Como se pode notar, não está garantido o direito absoluto à propriedade privada, mas sim à propriedade que cumpre sua função social ${ }^{47}$.

Segundo o pensamento liberal, a propriedade existia apenas para atender à vontade do proprietário que poderia fazer tudo aquilo que não estivesse vedado em lei. Tratava-se de um direito individual que impunha prestações negativas,

44 GRECO, Marco Aurélio. Crise do Formalismo no Direito Tributário Brasileiro.

45BRASIL. Assembleia Nacional Constituinte. Constituição da República Federativa do Brasilde 05 de Outubro de 1988.

46 BRASIL. Assembleia Nacional Constituinte. Constituição da República Federativa do Brasilde 05 de Outubro de 1988.

47 TEPEDINO, Gustavo; SCHREIBER, Anderson. A garantia da propriedade no Direito Brasileiro. Revista da Faculdade de Direito de Campos, Campos, ano VI, n. 6, p. 101-119, jun/2005. 
LEÃO, Celina; FRIAS, Lincoln. Os objetivos da tributação: a interpretação liberal e a interpretação social da propriedade privada. Revista Eletrônica Direito e Política, Programa de Pós-Graduação Stricto Sensu em Ciência Jurídica da UNIVALI, Itajaí, v.12, n.3, $3^{\circ}$ quadrimestre de 2017. Disponível em: www.univali.br/direitoepolitica - ISSN 1980-7791

prestações de abstenção aos terceiros, de não violação da propriedade alheia. Prova disso é a norma do art. 524 do Código Civil Brasileiro de 1916 que, com forte inspiração no Código Napoleônico de origem liberal, estabelecia que a lei assegurava ao proprietário o direito de usar, gozar, usufruir e dispor de seus bens, e de reavê-los do poder de quem quer que injustamente os possuísse ${ }^{48}$; um direito estabelecido apenas pela ótica do proprietário em seu interesse próprio. Semelhante norma estava presente nos códigos civis da França e da Itália de $1846^{49}$.

Ao longo do tempo, porém, o direito de propriedade foi sendo reformulado, perdendo essa conotação exclusiva privada, sobretudo por meio da consagração constitucional em vários ordenamentos jurídicos da função social da propriedade, aplicando-se a interpretação social do patrimônio individual. Trata-se da mudança denominada publicização da propriedade ou funcionalização social dos institutos jurídicos, "em razão da prioridade atribuída, pela Constituição, à pessoa humana, sua dignidade, sua personalidade e seu livre desenvolvimento"50. A separação estanque entre público e privado, tão cara ao liberalismo, vai cedendo espaço para institutos jurídicos que, apesar de classicamente estarem na ordem privada, vão tendo seu conteúdo alterado para atender às finalidades sociais consagradas na Constituição, mesclando-se o público e o privado em um mesmo direito, atendendo ao interesse de ambos. "Sob a ótica da funcionalização busca-se a reconstrução dos principais institutos

48 BRASIL. Presidência da República. Lei no 3.071 de 01 de janeiro de 1916. Institui o Código Civil dos Estados Unidos do Brasil. Disponível em: http://www.planalto.gov.br/ccivil_03/Leis/ L3071. htm. Acesso em: 16 maio 2015.

49 TEPEDINO, Gustavo; SCHREIBER, Anderson. A garantia da propriedade no Direito Brasileiro.

50 MORAES, Maria Celina Bodin. A caminho de um Direito Civil Constitucional. Revista Estado, Direito e Sociedade, Rio de Janeiro, v. 1, 1991. Disponível em: <http://www.grupoddp.com.br/resources/A\%20Caminho\%20do\%20Direito\%20CivilConstitucional\%20-\%20Maria\%20Celina\%20 Bodin\%20de\%20Moraes.pdf>. Acesso em: 11 novembro 2015. 
LEÃO, Celina; FRIAS, Lincoln. Os objetivos da tributação: a interpretação liberal e a interpretação social da propriedade privada. Revista Eletrônica Direito e Política, Programa de Pós-Graduação Stricto Sensu em Ciência Jurídica da UNIVALI, Itajaí, v.12, n.3, $3^{\circ}$ quadrimestre de 2017. Disponível em: www.univali.br/direitoepolitica - ISSN 1980-7791

do Direito, a fim de alcançar novo equilíbrio entre os interesses manifestamente individualistas e as necessidades coletivas e sociais" 51.

Há quem defenda que o conceito social de propriedade remonte à Summa Theologica de São Tomás de Aquino ${ }^{52}$. A maioria da doutrina, porém, aponta Leon Duguit como o precursor da ideia de legitimação do direito de propriedade no interesse social, como um dever social, atribuindo a esse autor a criação da expressão "função social da propriedade", já no início do século $X^{53}$.

Na formulação de Duguit, o proprietário não é titular de um direito subjetivo, mas sim o detentor de uma riqueza que deve ter fruição socialmente útil ${ }^{54}$, somente merecendo proteção estatal a propriedade produtiva. Duguit ${ }^{55}$ critica a ideia liberal de que a propriedade é um direito natural, individual e absoluto porque nenhum homem vive seu direito de propriedade em uma realidade isolada; ele faz parte de uma comunidade e vive de forma interdependente com outros, cada um realizando sua função. Se o indivíduo vivesse de forma completamente autônoma e isolada dos demais, não haveria a necessidade de um direito que exigisse respeito de terceiros, pois o isolamento já lhe garantiria o exercício da propriedade de forma inviolável. Colocar a propriedade em função

51SOARES, Vivian Bacaro Nunes. Interpretação da função social da propriedade na CF/88, à luz dos fundamentos da socialidade, fraternidade e dignidade da pessoa humana. XVII CONGRESSO DA CONPEDI, 2008, Brasília. Anais do ... Brasília, p. 6.932. Disponível em: <http://www.conpedi.org.br/manaus/arquivos/anais/brasilia/20_548.pdf>. Acesso em: 3 maio 2015.

52 BELLO, Enzo. A teoria política da propriedade na Era Moderna: ascensão e crítica do individualismo possessivo.

53 TEPEDINO, Gustavo. O Papel do Poder Judiciário na efetivação da função social da propriedade. In: STROKAZE, Jovelino José (Org.). Questões Agrárias. Julgados Comentados e Pareceres. São Paulo: Método, 2002. p. 91-131.

54 LEONETTI, Carlos Araújo. Função social da propriedade: mito ou realidade. Sequência: estudos jurídicos e políticos, Florianópolis, v. 19, n. 38, 1998. Disponível em: <https://periodicos.ufsc.br/ index.php/sequencia/article/view/15605>. Acesso em: 15 abril 2015.

55 FOSTER, Scheila R.; BONILLA, Daniel. The social function of property: a comparative law perspective. Fordham Law Review, New York, vol. 80, p. 101-113, 2011. 
LEÃO, Celina; FRIAS, Lincoln. Os objetivos da tributação: a interpretação liberal e a interpretação social da propriedade privada. Revista Eletrônica Direito e Política, Programa de Pós-Graduação Stricto Sensu em Ciência Jurídica da UNIVALI, Itajaí, v.12, n.3, $3^{\circ}$ quadrimestre de 2017. Disponível em: www.univali.br/direitoepolitica - ISSN 1980-7791

da sociedade é colocá-la em produção, isto é, colocá-la em prol do bem-estar geral ${ }^{56}$.

Norma paradigmática é a previsão na Constituição de Weimar de 1919 sobre o ônus inerente à propriedade privada. Em uma tradução literal, a norma estabelece que a propriedade obriga ${ }^{57}$, isto é, aquele que detém propriedade não possui apenas direitos, mas também deveres. Esta norma é considerada a responsável por elevar a função social da propriedade a um direito constitucional $^{58}$.

No Pacto de San José da Costa Rica (Convenção Americana sobre os Direitos Humanos), de 1969, o direito de propriedade foi submetido ao interesse social. Há previsão da função social da propriedade nas Constituições do México e da Colômbia. Na Constituição da África do Sul de 1996, após o fim do Apartheid, foi estabelecido que o Estado deve tomar medidas legislativas e de outras naturezas para promover condições que possibilitem aos cidadãos ter acesso à terra de forma equitativa 59 .

No Brasil, a legislação colonial das sesmarias previa a obrigação de cultivar a terra, dando-Ihe aproveitamento econômico. Eram grandes propriedades, concentradas nas mãos de poucos possuidores que as cultivavam em regime de monocultura e com mão de obra escrava. Com a independência do país, a propriedade das sesmarias foi consolidada para aqueles que as possuíam, estabelecendo a Lei de Terras de 1850 a propriedade como um direito individual

56 FOSTER, Scheila R.; BONILLA, Daniel. The social function of property: a comparative law perspective.

57 VARELA, Laura Beck; LUDWIG, Marcos de Campos. Da Propriedade às Propriedades: função social e reconstrução de um direito. In: MARTINS-COSTA, Judith (Org.). A reconstrução do direito privado. São Paulo: Editora Revista dos Tribunais, 2002. p. 769.

58 FACHIN, Luiz Edson. A função social da posse e a propriedade contemporânea. Porto Alegre: Fabris, 1988.

59 ALEXANDER, Gregory S. The Social-obligation norm in American property law. Cornell Law Library, Ithaca, v. 92, p. 782-783, mai. 2009. 
LEÃO, Celina; FRIAS, Lincoln. Os objetivos da tributação: a interpretação liberal e a interpretação social da propriedade privada. Revista Eletrônica Direito e Política, Programa de Pós-Graduação Stricto Sensu em Ciência Jurídica da UNIVALI, Itajaí, v.12, n.3, $3^{\circ}$ quadrimestre de 2017. Disponível em: www.univali.br/direitoepolitica - ISSN 1980-7791

e absoluto ${ }^{60}$. Nas Constituições Brasileiras de $1824^{61}$ (art. 179, inc. XXII), $1891^{62}$ (art. 72), $1934^{63}$ (art. 113) e $1937^{64}$ (art. 122, inc. XIV e art. 123) havia a previsão da inviolabilidade do direito de propriedade, salvo em caso de desapropriação por interesse público, mediante prévia indenização, apenas sendo acrescido na Constituição de 1934 que a propriedade privada não poderia ser exercida contra o interesse social ou coletivo (art. 113, inc. XVII). Os textos constitucionais refletiam o pensamento liberal dominante, a interpretação liberal da propriedade privada.

A Constituição do Brasil de 194665, inspirada na Constituição de Weimar, apresentou significativo incremento ao estabelecer que o uso da propriedade estava condicionado ao bem-estar social e, caso a propriedade rural não tivesse uma exploração adequada àquele condicionamento, poderia ser desapropriada (art. 147), com prévia indenização em títulos públicos. Somente na Constituição de $1967^{66}$, no art. 157 , inc. III, foi introduzida a função social da propriedade.

60 BRASIL. Imperador Constitucional do Brasil. Lei no 601 de 18 de setembro de 1850. Dispõe sobre as terras devolutas do Império. Disponível em: http://www.planalto.gov.br/ ccivil_03/LEIS/L06011850.htm. Acesso em: 9 setembro 2015.

61 BRASIL. Conselho de Estado. Constituição Política do Império do Brasil de 22 de abril de 1824. Disponível em: http://www.planalto.gov.br/ccivil_03/Constituicao/Constituicao24.htm. Acesso em: 2 junho 2015.

62 BRASIL. Congresso Nacional. Constituição da República dos Estados Unidos do Brasilde 24 de Fevereiro de 1891. Disponível em: http://www.planalto.gov.br/ ccivil_03/Constituicao/ Constituicao91.htm. Acesso em: 1 junho 2015.

63 BRASIL. Assembleia Nacional Constituinte. Constituição da República dos Estados Unidos do Brasil de 16 de julho de 1934. Disponível em: http://www.planalto.gov.br/ ccivil_03/Constituicao /Constituicao34.htm. Acesso em: 2 junho 2015.

64 BRASIL. Presidência da República. Constituição dos Estados Unidos do Brasil de 10 de novembro de 1937. Disponível em: http://www.planalto.gov.br/ccivil_03/Constituicao/ Constituicao37.htm. Acesso em: 5 agosto 2015.

65 BRASIL. Assembleia Constituinte. Constituição dos Estados Unidos do Brasilde 18 de setembro de 1946. Disponível em: http://www.planalto.gov.br/ccivil_03/Constituicao/ Constituicao46.htm. Acesso em: 2 junho 2015.

66 BRASIL. Congresso Nacional. Constituição da República Federativa do Brasilde 24 de janeiro de 1967. Disponível em: http://www.planalto.gov.br/ccivil_03/Constituicao/ Constituica067.htm. Acesso em: 1 junho 2015. 
LEÃO, Celina; FRIAS, Lincoln. Os objetivos da tributação: a interpretação liberal e a interpretação social da propriedade privada. Revista Eletrônica Direito e Política, Programa de Pós-Graduação Stricto Sensu em Ciência Jurídica da UNIVALI, Itajaí, v.12, n.3, $3^{\circ}$ quadrimestre de 2017. Disponível em: www.univali.br/direitoepolitica - ISSN 1980-7791

O grande avanço da CF/88 frente às constituições brasileiras anteriores é que naquelas a função social era prevista como um princípio da ordem econômica, enquanto que no ordenamento atual ela é um direito fundamental, que deve ser respeitado por normas de qualquer índole, não apenas econômica. Por estar elencada no rol dos direitos e garantias individuais do art. $5^{\circ}$ da CF/88, a função social da propriedade é cláusula pétrea, ou seja, não pode ser objeto de alteração legislativa que a retire ou diminua seu alcance no ordenamento jurídico ${ }^{67}$, conforme estabelecido no inc. IV do $\S 4^{\circ}$ do art. 60 da Carta Constitucional ${ }^{68}$.

Em um primeiro momento, existiam duas correntes na doutrina brasileira sobre a natureza da função social da propriedade: uma, de caráter mais privado, a colocava como uma limitação ao exercício do direito de propriedade, sendo uma manifestação do poder de polícia do Estado; a outra, dando ênfase a seu caráter constitucional, a abordava como um instrumento para a obtenção da ordem econômica e social por meio da justiça social ${ }^{69}$.

A primeira corrente teria sido dominante no Brasil no século $X X$ e influenciado o teor do Código Civil de 1916, apontando a função social da propriedade como uma limitação que somente poderia ser criada por lei, por se tratar de uma desvantagem que diminui o escopo inicial individual de proteção do direito de propriedade $^{70}$.

Porém, pela corrente que vem se firmando na doutrina brasileira com fundamento na lição de Duguit, a função social da propriedade não se trata de uma limitação externa ao direito de propriedade ${ }^{71}$. Isso porque, se assim se

67 SILVA, José Afonso da. Curso de Direito Constitucional. 9. ed. São Paulo: Malheiros, 1994.

68 BRASIL. Assembleia Nacional Constituinte. Constituição da República Federativa do Brasilde 05 de Outubro de 1988.

69 DI PIETRO, Maria Sylvia Zanella. Direito Administrativo. 3. ed. São Paulo: Atlas, 1992.

70 CUNHA, Alexandre dos Santos. The social function of property in Brazilian Law. Fordham Law Review, New York, v. 80, p. 1171-1181, 2011.

71 MORAES, Maria Celina Bodin. A caminho de um Direito Civil Constitucional. 
LEÃO, Celina; FRIAS, Lincoln. Os objetivos da tributação: a interpretação liberal e a interpretação social da propriedade privada. Revista Eletrônica Direito e Política, Programa de Pós-Graduação Stricto Sensu em Ciência Jurídica da UNIVALI, Itajaí, v.12, n.3, $3^{\circ}$ quadrimestre de 2017. Disponível em: www.univali.br/direitoepolitica - ISSN 1980-7791

entendesse, seria permitido que a simples alteração da norma, retirando a função social do ordenamento jurídico, possibilitasse o retorno a uma propriedade eminentemente individual e privada.

A propriedade permanece privada, mas sua utilização e sua finalidade é o bem coletivo. Os instrumentos estabelecidos na Constituição Federal para cumprimento da função social da propriedade têm por característica comum serem instrumentos que exigem um agir do proprietário, um comportamento positivo de dar à propriedade uma destinação útil; por exemplo, para a propriedade urbana as funções primordiais de moradia, de bem estar e de cidades sustentáveis e para a propriedade rural a função de produção e preservação do meio-ambiente. A destinação social da propriedade reflete o conceito de que esta não pode ser usada no estrito interesse de seu possuidor ou proprietário, mas sim no interesse que coadune com o melhor desenvolvimento social $^{72}$.

A funcionalização da propriedade privada por meio de uma norma constitucional estabelece deveres para o proprietário, para o legislador infraconstitucional e para o gestor público, que devem concretizar o princípio nas normas e políticas de suas competências. Trata-se de "um cânone hermenêutico e integrativo, fonte de deveres jurídicos e limite ao exercício de direitos subjetivos" 73 . Por decorrência, na visão da gestão pública, a função social da propriedade urbana, por exemplo, determina ser dever do gestor formular um plano diretor do munícipio cujas diretrizes considerem "as variáveis socioambientais das cidades,

\section{SILVA, José Afonso da. Curso de Direito Constitucional.}

COMPARATO, Fábio Konder. Direitos e deveres fundamentais em matéria de propriedade. In: STROZAKE, Jovelino José (Org.). A questão agrária e a justiça. São Paulo: Revista dos Tribunais, 2000. p. 130-147.

72 BRASIL. Superior Tribunal de Justiça. Recurso Especial n 1.144.982/PR. Recorrente: Fazenda Nacional. Recorrido: Gelza Regina de Abreu Moresco. Relator: Min. Mauro Campbell Marques, Segunda Turma. Brasília, 15 de outubro de 2009d.

73 VARELA, Laura Beck; LUDWIG, Marcos de Campos. Da Propriedade às Propriedades: função social e reconstrução de um direito. p. 778. 
LEÃO, Celina; FRIAS, Lincoln. Os objetivos da tributação: a interpretação liberal e a interpretação social da propriedade privada. Revista Eletrônica Direito e Política, Programa de Pós-Graduação Stricto Sensu em Ciência Jurídica da UNIVALI, Itajaí, v.12, n.3, $3^{\circ}$ quadrimestre de 2017. Disponível em: www.univali.br/direitoepolitica - ISSN 1980-7791

que enfatizam a sustentabilidade urbana, o cenário de diversidade social que caracteriza as cidades" ${ }^{\prime 74}$.

No ordenamento jurídico brasileiro há diversas normas que indicam não ser a propriedade um direito absoluto. Por previsao constitucional, a propriedade pode sofrer tributação progressiva em três situações: em razão das suas características de tamanho e localização urbana; quando seu proprietário não Ihe dá a destinação urbana estabelecida no plano diretor do município e quando a mantém como grande propriedade rural improdutiva ( $\S 4^{\circ}$ do art. 182 e $\S 4^{\circ}$ do art. $153^{75}$ ). Esses requisitos objetivos dão maior concretude ao que seja atingir a função social da propriedade, algo que outrora era um princípio de conteúdo indeterminado.

Para a propriedade rural, a CF/88 estabelece no art. 186 que a propriedade cumpre sua função social quando atende, simultaneamente, segundo critérios e graus de exigência estabelecidos em lei, os requisitos de aproveitamento racional e adequado, utilização adequada dos recursos naturais disponíveis e preservação do meio ambiente, observância das disposições que regulam as relações de trabalho e exploração que favoreça o bem-estar dos proprietários e dos trabalhadores ${ }^{76}$. Em caso de descumprimento dos requisitos constitucionais, a propriedade poderá ser desapropriada pela União por interesse social para fins de reforma agrária, nos termos do art. 184 da CF $/ 88^{77}$. De outro lado, conforme o $\S 2^{\circ}$ do art. $182^{78}$, a propriedade urbana cumpre sua função social quando

74 REZENDE, Denis Alcides; ULTRAMARI, Clovis. Plano diretor e planejamento estratégico municipal: introdução teórico conceitual. Revista de Administração Pública, Rio de Janeiro, v. 41 , p. $258,2007$.

75 BRASIL. Assembleia Nacional Constituinte. Constituição da República Federativa do Brasilde 05 de Outubro de 1988.

76 BRASIL. Assembleia Nacional Constituinte. Constituição da República Federativa do Brasilde 05 de Outubro de 1988.

77 BRASIL. Assembleia Nacional Constituinte. Constituição da República Federativa do Brasilde 05 de Outubro de 1988.

78 BRASIL. Assembleia Nacional Constituinte. Constituição da República Federativa do Brasilde 05 de Outubro de 1988. 
LEÃO, Celina; FRIAS, Lincoln. Os objetivos da tributação: a interpretação liberal e a interpretação social da propriedade privada. Revista Eletrônica Direito e Política, Programa de Pós-Graduação Stricto Sensu em Ciência Jurídica da UNIVALI, Itajaí, v.12, n.3, $3^{\circ}$ quadrimestre de 2017. Disponível em: www.univali.br/direitoepolitica - ISSN 1980-7791

atende às exigências fundamentais de ordenação da cidade do plano diretor do município.

Além das disposições constitucionais mencionadas, há normas infraconstitucionais que traduzem a submissão do direito de propriedade ao interesse social. Por exemplo, as restrições administrativas previstas no DecretoLei $n^{\circ} 25 / 37^{79}$ referentes ao uso das propriedades tombadas como patrimônio histórico e artístico nacional, as conformações ao direito de construir referentes a recuos e coeficientes de construção estabelecidas em leis municipais, o Código de Minas $^{80}$ quando dispõe sobre $o$ uso de terrenos vizinhos a jazidas, a Lei $n^{0}$ $4.515 / 64^{81}$ que dispõe sobre construções próximas a aeroportos, dentre outros. O Código Civil vigente ${ }^{82}$ também aponta na direção da publicização do direito privado de propriedade. $\mathrm{O}$ art. 1276 estabelece que o imóvel urbano ou rural que seja intencionalmente abandonado por seu proprietário - intenção esta presumida pelo não pagamento dos ônus fiscais da propriedade - e que não esteja na posse de outrem poderá ser arrecadado como bem público.

Nos julgamentos proferidos no Brasil é cada vez mais clara a tendência de se considerar a função social como algo intrínseco à propriedade privada. Na Ação Declaratória de Inconstitucionalidade (ADI) no 2.213 MC/DF, o Min. Celso de Mello do Supremo Tribunal Federal reconheceu que

79 BRASIL. Decreto-Lei no 25, de 30 de novembro de 1937. Organiza a proteção do patrimônio histórico e artístico nacional. Diário Oficial da União, Poder Executivo, Rio de Janeiro, RJ, 6 dez. 1937. Disponível em: <http://www.planalto.gov.br/ccivil_03/Decreto-Lei/Del0025.htm>. Acesso em: 10 agosto 2015

80 BRASIL. Decreto-Lei no 227, de 28 de fevereiro de 1967.Dá nova redação ao Decreto-lei no 1.985, de 29 de janeiro de 1940 (Código de Minas). Diário Oficial da União, Poder Executivo, Brasília, DF, 28 fev. 1967. Disponível em: http://www.planalto.gov.br/ccivil_03/ decretolei/Del0227.htm. Acesso em: 10 agosto 2015.

81 BRASIL. Lei no 4.515, de 1 de dezembro de 1964. Dispõe sobre a zona de proteção dos aeroportos. Diário Oficial da União, Poder Executivo, Brasília, DF, 4 dez. 1964. Disponível em: <http://www.planalto.gov.br/ccivil_03/LEIS/1950-1969/L4515.htm>. Acesso em: 10 agosto de 2015.

82 BRASIL. Lei no 10.406, de 10 de janeiro de 2002. Institui o Código Civil. Diário Oficial da União, Poder Executivo, Brasília, DF, 11 jan. 2002. Disponível em: <http://www.planalto.gov.br/ ccivil_03/Leis/2002/L10406.htm>. Acesso em: 9 agosto 2015. 
LEÃO, Celina; FRIAS, Lincoln. Os objetivos da tributação: a interpretação liberal e a interpretação social da propriedade privada. Revista Eletrônica Direito e Política, Programa de Pós-Graduação Stricto Sensu em Ciência Jurídica da UNIVALI, Itajaí, v.12, n.3, $3^{0}$ quadrimestre de 2017. Disponível em: www.univali.br/direitoepolitica - ISSN 1980-7791

O direito de propriedade não se reveste de caráter absoluto, eis que, sobre ele, pesa grave hipoteca social, a significar que, descumprida a função social que lhe é inerente ( $\mathrm{CF}$, art. 50, XXIII), legitimar-se-á a intervenção estatal na esfera dominial privada ${ }^{83}$.

No REsp $\mathrm{n}^{0}$ 27.039/SP84, com base na função social da propriedade, o Superior Tribunal de Justiça decidiu que os hospitais particulares são obrigados a aceitar o ingresso de médicos que não fazem parte de seu corpo clínico e de seus respectivos pacientes em suas dependências, visto que a saúde é direito de todos e o interesse privado do proprietário do hospital está submetido ao interesse social da propriedade.

Em relação à propriedade rural, o Tribunal de Justiça do Rio Grande do Sul no Agravo de Instrumento $n^{\circ} 598.360 .402^{85}$ decidiu que os direitos fundamentais à moradia e ao trabalho de 600 famílias acampadas em uma propriedade rural particular devem prevalecer sobre o direito do proprietário, tendo em vista que, em que pese houvesse produção na terra invadida, tratava-se de propriedade que não cumpria sua função social por não pagar os tributos relativos àquele imóvel. Esse julgamento faz uma interessante leitura do art. 185 da $\mathrm{CF} / 88^{86}$, pois segundo tal norma as propriedade produtivas não poderiam ser desapropriadas. Ao estabelecer que uma propriedade inadimplente com o ITR pode ser considerada uma propriedade improdutiva, mesmo que nela haja determinada produção, a jurisprudência citada abre caminho para que seja

83 BRASIL. Supremo Tribunal Federal. Ação Declatória de Inconstitucionalidade no 2.213 MC /DF. Requerente: Partido dos Trabalhadores e outro. Requerido: Presidente da República. Relator: Min. Celso de Mello, Tribunal Pleno. Brasília, 23 de julho de 2004a. Disponível em: $<$ http://www.stf.jus.br/portal/processo/verProcessoAndamento.asp?incidente $=1823899>$. Acesso em: 10 maio 2015.

84 BRASIL. Superior Tribunal de Justiça. Recurso Especial no 27.039/SP. Recorrente: Irmandade do Hospital Francisco Rosas. Recorrido: Lúcio Godoi Fermoselli. Relator: Min. Nilson Naves, Terceira Turma. Brasília. Julgado em 08/11/1993, publicado em 07/02/1994.

85 RIO GRANDE DO SUL. Tribunal de Justiça. Agravo de Instrumento no 598.360.402. Agravante: José Cenci. Agravado: Merlin S/A Indústria e Comércio de Óleos Vegetais. Relatora: Des. Elba Aparecida Nicolli Bastos, 19a Câmara Cível. Porto Alegre. Julgado em 6/10/1998, publicado em 05/11/1998.

86 BRASIL. Assembleia Nacional Constituinte. Constituição da República Federativa do Brasilde 05 de Outubro de 1988. 
LEÃO, Celina; FRIAS, Lincoln. Os objetivos da tributação: a interpretação liberal e a interpretação social da propriedade privada. Revista Eletrônica Direito e Política, Programa de Pós-Graduação Stricto Sensu em Ciência Jurídica da UNIVALI, Itajaí, v.12, n.3, $3^{\circ}$ quadrimestre de 2017. Disponível em: www.univali.br/direitoepolitica - ISSN 1980-7791

considerada improdutiva toda a propriedade que não cumpra os requisitos da função social estabelecidos no art. 186 ou outros relativos aos deveres do proprietário rural.

Enfim, diante do exposto, observa-se que tanto a legislação quanto a jusrisprudência brasileiras têm adotado a interpretação social da propriedade privada na medida em que exigem que ela cumpra sua função social.

\section{CONSIDERAÇÕES FINAIS}

A desigualdade na distribuição das riquezas mundiais atualmente é comparável à desigualdade do início do século XX. Aqueles que compõem o $1 \%$ mais rico da população mundial detêm quase $50 \%$ do patrimônio total e a metade economicamente inferior da população possui menos de $5 \%{ }^{87}$. Não há, nas leis de mercado, "forças de convergência que conduzam naturalmente a uma redução da desigualdade da riqueza ou a uma estabilização harmoniosa"88.

Diante desses dados, para que se almeje uma sociedade mais igualitária, é preciso que o Estado lance mão de todos os instrumentos gerenciais de diminuição da disparidade econômica e social, dentre eles o tributo. Para concretizar os objetivos estatais constitucionais e os direitos fundamentais, dá-se à tributação uma função para além da arrecadação, uma função que Ihe permite, por exemplo, desenhar os contornos de como deve ser exercida a propriedade para ser socialmente responsável e promover a redução da desigualdade social por meio de tributos que identifiquem pelas características do patrimônio a capacidade contributiva de cada cidadão.

Segundo a interpretação liberal, o patrimônio individual é definido de acordo com a situação pré-tributária, anterior à atuação estatal, sendo a tributação uma limitação do direito à propriedade. Em contraposição, de acordo com a interpretação social, deve-se definir o patrimônio individual como o resultado

87 PIKETTY, Thomas. O capital no século XXI. Rio de Janeiro: Intrínseca, 2014. p. 427.

88 PIKETTY, Thomas. O capital no século XXI. p. 367. 
LEÃO, Celina; FRIAS, Lincoln. Os objetivos da tributação: a interpretação liberal e a interpretação social da propriedade privada. Revista Eletrônica Direito e Política, Programa de Pós-Graduação Stricto Sensu em Ciência Jurídica da UNIVALI, Itajaí, v.12, n.3, $3^{\circ}$ quadrimestre de 2017. Disponível em: www.univali.br/direitoepolitica - ISSN 1980-7791

pós-tributário, pois a legislação, inclusive a tributária, é quem cria a propriedade. As pessoas não têm direito natural à propriedade, elas têm direito apenas ao patrimônio pós-tributário.

Como foi visto, a CF/88 publicizou um direito que antes era tido como eminentemente individual ao garantir um direito de propriedade desde que ela cumpra sua função social. O exercício do direito de propriedade impõe deveres ao proprietário em um agir positivo em relação à realidade social que o cerca. $\mathrm{A}$ propriedade permanece um patrimônio privado, mas que deve ser utilizada em prol do bem comum.

Portanto, a tributação pode ser um instrumento de atuação do Estado para concretizar seus objetivos, em especial o de uma sociedade menos desigual. Isso significa que não condiz com o ordenamento jurídico vigente o exercício de um direito de propriedade estritamente individual, conforme apregoado na interpretação liberal da propriedade.

Não há nenhuma força natural que possa desconcentrar a propriedade sem a intervenção de políticas públicas, em especial, a tributação como um meio de alinhar a propriedade privada ao interesse comum ${ }^{89}$. A capacidade do sistema tributário de alterar o comportamento dos cidadãos é tão grande que no "cerne de cada transformação política importante, encontramos uma revolução fiscal"90.

89 PIKETTY, Thomas. $\mathbf{O}$ capital no século $\mathbf{X X I}$.

90 PIKETTY, Thomas. O capital no século XXI. p. 480. 
LEÃO, Celina; FRIAS, Lincoln. Os objetivos da tributação: a interpretação liberal e a interpretação social da propriedade privada. Revista Eletrônica Direito e Política, Programa de Pós-Graduação Stricto Sensu em Ciência Jurídica da UNIVALI, Itajaí, v.12, n.3, $3^{\circ}$ quadrimestre de 2017. Disponível em: www.univali.br/direitoepolitica - ISSN 1980-7791

\section{REFERÊNCIAS DAS FONTES CITADAS}

ALEXANDER, Gregory S. The Social-obligation norm in American property law. Cornell Law Library, v. 92, p. 745-819, 2009.

ALVES, Marco Antônio Sousa. O direito de apropriação privada em Locke: um pensamento de transição. Revista Controvérsia, v. 6, n. 3, p. 51-67, 2010.

ANDERSON, Perry. Balanço do Neoliberalismo. In: SADER, Emir; GENTILI, Pablo (Orgs.).Pós-neoliberalismo: as políticas sociais e o Estado democrático. Rio de Janeiro: Paz e Terra, 1995. p. 9-23.

BALEEIRO, Aliomar. Limitações constitucionais ao poder de tributar. 7 ed. Rio de Janeiro: Forense, 1997.

BELLO, Enzo. A teoria política da propriedade na Era Moderna: ascensão e crítica do individualismo possessivo. In: MOTA, Maurício (Org.). Transformações do Direito de Propriedade Privada. Rio de Janeiro: Elsevier, 2009. p. 129-146.

BRASIL. Assembleia Nacional Constituinte. Constituição da República dos Estados Unidos do Brasil de 16 de julho de 1934. Disponível em: <http:// www.planalto.gov.br/ccivil_03/Constituicao/Constituicao34.htm>. Acesso em: 2 junho 2015.

Assembleia Constituinte. Constituição dos Estados Unidos do
Brasilde 18 de setembro de 1946. Disponível em: <http://www.planalto.gov.br/ccivil_03/ Constituicao/Constituicao46.htm>. Acesso em: 2 junho 2015.

Assembleia Nacional Constituinte. Constituição da República Federativa do Brasilde 05 de Outubro de 1988. Disponível em: <http://www.planalto.gov.br/ ccivil_03/Constituicao/Constituicao.htm>. Acesso em: 1 junho 2015.

. Congresso Nacional. Constituição da República dos Estados Unidos do Brasilde 24 de Fevereiro de 1891. Disponível em: <http://www.planalto.gov.br/ccivil__03/Constituicao/Constituicao91.htm>. Acesso em: 1 junho 2015.

$\begin{array}{cccccc} & \text { Congresso Nacional. Constituição da República Federativa do } \\ \text { Brasilde } & 24 & \text { de janeiro de } 1967 . \quad \text { Disponível em: }\end{array}$ <http://www.planalto.gov.br/ccivil_03/_Constituicao/Constituicao67.htm>. Acesso em: 1 junho 2015.

. Conselho de Estado. Constituição Política do Império do Brasil de 22 de abril de 1824.2 Disponível em: <http://www.planalto.gov.br/ccivil_03/Constituicao/ Constituicao24.htm> . Acesso em: 2 junho 2015. 
LEÃO, Celina; FRIAS, Lincoln. Os objetivos da tributação: a interpretação liberal e a interpretação social da propriedade privada. Revista Eletrônica Direito e Política, Programa de Pós-Graduação Stricto Sensu em Ciência Jurídica da UNIVALI, Itajaí, v.12, n.3, $3^{\circ}$ quadrimestre de 2017. Disponível em: www.univali.br/direitoepolitica - ISSN 1980-7791

Decreto-Lei no 25, de 30 de novembro de 1937. Organiza a proteção do patrimônio histórico e artístico nacional. Diário Oficial da União, Poder Executivo, Rio de Janeiro, RJ, 6 dez. 1937b. Disponível em: <http://www.planalto.gov.br/ccivil _03/Decreto-Lei/Del0025.htm>. Acesso em: 10 agosto 2015.

Decreto-Lei no 227, de 28 de fevereiro de 1967.Dá nova redação ao Decreto-lei no 1.985, de 29 de janeiro de 1940 (Código de Minas). Diário Oficial da União, Poder Executivo, Brasília, DF, 28 fev. 1967. Disponível em: <http://www. planalto.gov.br/ccivil_03/decreto-lei/Del0227.htm>. Acesso em: 10 agosto 2015.

Imperador Constitucional do Brasil. Lei no 601 de 18 de setembro de 1850. Dispõe sobre as terras devolutas do Império. Disponível em: <http://www.planalto. gov.br/ccivil_03/LEIS/L0601-1850.htm>. Acesso em: 9 setembro 2015.

Lei no 4.515 , de 1 de dezembro de 1964. Dispõe sobre a zona de proteção dos aeroportos. Diário Oficial da União, Poder Executivo, Brasília, DF, 4 dez. 1964. Disponível em: <http://www.planalto.gov.br/ccivil_03/LEIS/19501969/L4515.htm>. Acesso em: 10 agosto de 2015.

. Lei no 5.172, de 25 de outubro de 1966. Dispõe sobre o Sistema Tributário Nacional e institui normas gerais de direito tributário aplicáveis à União, Estados e municípios. Diário Oficial da União, Poder Executivo, Brasília, DF, 27 out. 1966. Disponível em: <http://www. planalto.gov.br/ccivil_03/Leis /L5172.htm>. Acesso em: 26 outubro 2015.

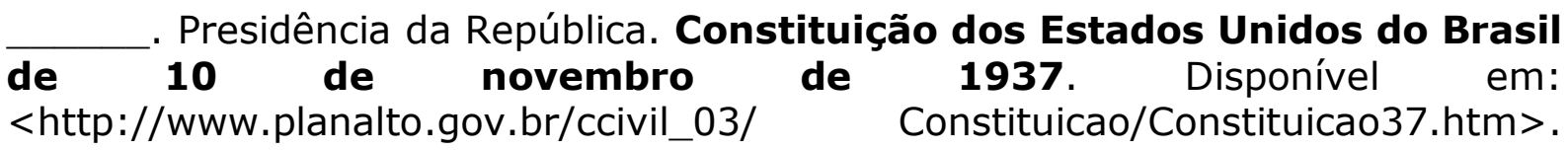

Acesso em: 5 agosto 2015.

Presidência da República. Lei no 3.071 de 01 de janeiro de 1916.

Institui o Código Civil dos Estados Unidos do Brasil. Disponível em: <http://www.planalto. gov.br/ccivil_03/Leis/L3071.htm>. Acesso em: 16 maio 2015.

BRASIL. Lei no 10.406, de 10 de janeiro de 2002. Institui o Código Civil. Diário Oficial da União, Poder Executivo, Brasília, DF, 11 jan. 2002. Disponível em: <http://www.planalto.gov.br/ ccivil_03/Leis/2002/L10406.htm>. Acesso em: 9 agosto 2015.

. Presidência da República. Lei no 12.469 de 26 de agosto de 2011.Altera os valores constantes da tabela do Imposto sobre a Renda da Pessoa Física. Disponível em: <http://www.planalto.gov.br/CCIVIL_03/_Ato20112014/2011/Lei/L12469.htm>. Acesso em: 10 novembro 2015. 
LEÃO, Celina; FRIAS, Lincoln. Os objetivos da tributação: a interpretação liberal e a interpretação social da propriedade privada. Revista Eletrônica Direito e Política, Programa de Pós-Graduação Stricto Sensu em Ciência Jurídica da UNIVALI, Itajaí, v.12, n.3, $3^{\circ}$ quadrimestre de 2017. Disponível em: www.univali.br/direitoepolitica - ISSN 1980-7791

Superior Tribunal de Justiça. Recurso Especial no 27.039/SP. Recorrente: Irmandade do Hospital Francisco Rosas. Recorrido: Lúcio Godoi Fermoselli. Relator: Min. Nilson Naves, Terceira Turma. Brasília. Julgado em 08/11/1993, publicado em 07/02/1994.

- Superior Tribunal de Justiça. Recurso Especial no 1.144.982/PR. Recorrente: Fazenda Nacional. Recorrido: Gelza Regina de Abreu Moresco. Relator: Min. Mauro Campbell Marques, Segunda Turma. Brasília, 15 de outubro de 2009d.

. Supremo Tribunal Federal. Ação Declatória de Inconstitucionalidade $\mathrm{n}^{\circ}$ 2.213 MC /DF. Requerente: Partido dos Trabalhadores e outro. Requerido: Presidente da República. Relator: Min. Celso de Mello, Tribunal Pleno. Brasília, 23 de julho de 2004a.

CARVALHO, Paulo de Barros. Curso de Direito Tributário. 17 ed. São Paulo: Saraiva, 2005.

COMPARATO, Fábio Konder. Direitos e deveres fundamentais em matéria de propriedade. In: STROZAKE, Jovelino José (Org.). A questão agrária e a justiça. São Paulo: Revista dos Tribunais, 2000. p. 130-147.

CUNHA, Alexandre dos Santos. The social function of property in Brazilian Law. Fordham Law Review, v. 80, p. 1171-1181, 2011.

DI PIETRO, Maria Sylvia Zanella. Direito Administrativo. 3. ed. São Paulo: Atlas, 1992.

FACHIN, Luiz Edson. A função social da posse e a propriedade contemporânea. Porto Alegre: Fabris, 1988.

FOSTER, Scheila R.; BONILLA, Daniel. The social function of property: a comparative law perspective. Fordham Law Review, vol. 80, p. 101-113, 2011.

GODOI, Marciano Seabra de. Extrafiscalidade y sus límites constitucionales. Revista Internacional de Direito Tributário, v.1, n.1, p. 219-262, 2004.

- Tributo e Solidariedade Social. In: GRECO, Marco Aurélio; GODOI, Marciano Seabra (Orgs.). Solidariedade Social e Tributação. São Paulo: Dialética, 2005. p. 141-167.

GRECO, Marco Aurélio. Crise do Formalismo no Direito Tributário Brasileiro. Revista da Procuradoria Geral da Fazenda Nacional, v.1, n.1, p. 9-18, 2011.

GREGÓRIO, Argos. Análise Doutrinária sobre o conceito de "capacidade contributiva" e a eleição de critérios para a sua formulação. Revista Brasileira de Direito Tributário e Finanças Públicas, n.12, p.5-20, 2009. 
LEÃO, Celina; FRIAS, Lincoln. Os objetivos da tributação: a interpretação liberal e a interpretação social da propriedade privada. Revista Eletrônica Direito e Política, Programa de Pós-Graduação Stricto Sensu em Ciência Jurídica da UNIVALI, Itajaí, v.12, n.3, $3^{\circ}$ quadrimestre de 2017. Disponível em: www.univali.br/direitoepolitica - ISSN 1980-7791

HAYEK, Friedrich August von. O caminho da servidão. Tradução de Anna Maria Capovilla, José Ítalo Stelle e Liane de Morais Ribeiro. São Paulo: Instituto Ludwig von Mises Brasil, 2010.

LEAL, Augusto Cesar de Carvalho. (In) Justiça Social por meio dos tributos: a finalidade redistributiva da tributação e a regressividade da matriz tributária brasileira. Revista Dialética de Direito Tributário, n. 196, p. 7-32, 2012.

LEONETTI, Carlos Araújo. Função social da propriedade: mito ou realidade. Sequência: estudos jurídicos e políticos, v. 19, n. 38, 1998.

LOCKE, John. Dois Tratados sobre o Governo. Tradução Júlio Ficher. São Paulo: Martins Fontes, 2005.

MELLO, Leonel Itaussu Almeida. Jonh Locke e o individualismo liberal. In: WEFFORT, Francisco C. (Org.). Os clássicos da política - vol. 1,13 ed. São Paulo: Ática, 2000, p. 79-110.

MORAES, Maria Celina Bodin. A caminho de um Direito Civil Constitucional. Revista Estado, Direito e Sociedade, v. 1, n. 1, 1991.

MURPHY, Liam; NAGEL, Thomas. O mito da propriedade. Tradução de Marcelo Brandão Cipolla. São Paulo: Martins Fontes, 2005.

NABAIS, José Casalta. O dever fundamental de pagar impostos. 3 ed. Lisboa: Almedina, 2012.

NOZICK, Robert. Anarquia, Estado e Utopia. Tradução de Ruy Jungmann. Rio de Janeiro: JZE, 1991.

PIKETTY, Thomas. O capital no século XXI. Rio de Janeiro: Intrínseca, 2014.

REZENDE, Denis Alcides; ULTRAMARI, Clovis. Plano diretor e planejamento estratégico municipal: introdução teórico conceitual. Revista de Administração Pública, v. 41, p. 255-271, 2007.

RIO GRANDE DO SUL. Tribunal de Justiça. Agravo de Instrumento no 598.360.402. Agravante: José Cenci. Agravado: Merlin S/A Indústria e Comércio de Óleos Vegetais. Relatora: Des. Elba Aparecida Nicolli Bastos, 19a Câmara Cível. Porto Alegre. Julgado em 6/10/1998, publicado em 05/11/1998.

SACCHETO, Cláudio. O dever de solidariedade no Direito Tributário: o Ordenamento Italiano. In: GRECO, Marco Aurélio; GODOI, Marciano (Orgs.). Solidariedade Social e Tributação. São Paulo: Dialética, 2005. p. 9-52.

SOARES, Vivian Bacaro Nunes. Interpretação da função social da propriedade na $\mathrm{CF} / 88$, à luz dos fundamentos da socialidade, fraternidade e dignidade da pessoa humana. XVII CONGRESSO DA CONPEDI, 2008, Brasília. Anais do ... Brasília, p. 6.929-6.945. 
LEÃO, Celina; FRIAS, Lincoln. Os objetivos da tributação: a interpretação liberal e a interpretação social da propriedade privada. Revista Eletrônica Direito e Política, Programa de Pós-Graduação Stricto Sensu em Ciência Jurídica da UNIVALI, Itajaí, v.12, n.3, $3^{\circ}$ quadrimestre de 2017. Disponível em: www.univali.br/direitoepolitica - ISSN 1980-7791

TEPEDINO, Gustavo; SCHREIBER, Anderson. A garantia da propriedade no Direito Brasileiro. Revista da Faculdade de Direito de Campos, Campos, ano VI, n. 6, p. 101-119, jun. de 2005.

. O Papel do Poder Judiciário na efetivação da função social da propriedade. In: STROKAZE, Jovelino José (Org.). Questões Agrárias. Julgados Comentados e Pareceres. São Paulo: Método, 2002. p. 91-131.

TORRES, Ricardo Lobo. Tratado de Direito Constitucional Financeiro e Tributário - vol. 4. Rio de Janeiro: Renovar, 2007.

VARELA, Laura Beck; LUDWIG, Marcos de Campos. Da Propriedade às Propriedades: função social e reconstrução de um direito. In: MARTINS-COSTA, Judith (Org.). A reconstrução do direito privado. São Paulo: Editora Revista dos Tribunais, 2002. p. 763-788.

Submetido em: julho de 2017

Aprovado em: agosto de 2017 